\title{
Empirical Study of Bank of Industry's Loan to the Development of Micro, Small and Medium Enterprises in Nigeria: (2002-2013)
}

\author{
Nwankwo, Odi. ${ }^{1} \bowtie$ \\ James, S.O. ${ }^{2}$ \\ Department of Banking and Finance, Kogi State University, Anyigba, Nigeria
}

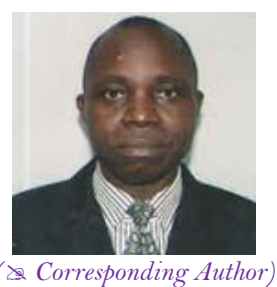

(D) Check for updates

\begin{abstract}
It has been the main objective of Nigerian government to achieve high rate of economic growth that would lead to high economic growth and reduce poverty level. The research is based on the implications of Bank of Industry and loan on development of Micro, small and medium enterprises in Nigeria. The problems noticed are that the lending of funds by Bank of Industry to micro, small and medium enterprises have not been very positive because of government unstable and inconsistent policies, high interest rate charged on loan and inability of customers to have access loan because of liquidity ratio of customers deposits. The research design used is expose fact research model involving events that have already taken place before the multiple linear regression analysis based on the classical regression methodology was used to form the main procedure that was fooled in this study. The findings are based on the implications of Bank industry's (BOI) interest rate on micro, small and medium Enterprises output in Nigeria; the effect of Bank of Industry's (BOI) interest rate MSMES output in Nigeria; the effect of availability of BOI credit proxies as total deposit on MSME output in Nigeria, the effect of Bank of Industry loan repayment on MSMES output. The study recommends that Bank of Industry should provide loans and advances to MSMES; reduction in the interest rate charged on loan there is need to redirect BOI focus on making Nigeria a producer nation through MSMES output in Nigeria.
\end{abstract}

Keywords: Bank of industry, Development, Micro, Small, Medium enterprises loans and interest rate.

\section{Introduction}

It has been the main objective of Nigerian government to achieve high rate of economic growth that would lead to high economic growth and reduce poverty level. This could be achieve through improvement of micro, small and medium enterprises (MSMES) output indicates the ability of an economy to increase and diversify the production of goods and series with stock of capital and (equity/debt) and other factors of production within the economy (Idowu, 2010; Akingunola, 2011).

Micro, small and medium Enterprises (MSMES) are theoretically and empirically established to be dependent on capital availability in form of equity or access to credit facilities from development financial institutions such as Bank of Industries and Micro finance banks (Douglas, 2012).

Nigeria government in 2001 established the Bank of Industry (BOI) Ltd as the major developmental financial institution.

This was created out of the merger of Nigerian Industrial Development Bank Limited NIDB and Nigeria Bank for commerce and Industries (NBCI) with the objective of providing financial assistance for the establishment of large, medium and small projects as well as expansion, diversification modernization of existing enterprises and rehabilitation of acting ones in Nigeria (Bank of Industries (BOI), 2012) Nigerian Industrial Bank ltd (NIDB) was establish 1964 under the control of World Bank with the International Finance Corporation (ITC) holding $75 \%$ equity and while the $25 \%$ was provided by Nigerian government.

The memorandum of association, the broad objective of the Nigerian Industrial Development Bank (NIDB) was to assist enterprises engaged in Industry, Commerce Agriculture and the exploitation of natural resources in the country.

The CBN, the Ministry of Finance and the Ministry of Industry were its supervising agencies. The Nigerian Bank for commerce and Industry (NBCI) was established in 1973 to promote the development of micro, small and medium size enterprises (MSMES) in the country until it was subsumed under the Bank of Industry, the principle 
function of NBCI has been the provision of long term investment financing and equity funds to micro, small and medium enterprises (Central Bank of Nigeria (CBN), 2012).

Nigerian government has gone a long way in reduction of poverty and other social economic problems in Nigerian has informed the decision of establishing a functional bank of Industry policy frame work in 2001.

The purpose of this was to stimulate sustainable real growth and development of industrial sector of Nigerian. The this has become more imperative in views of the limited capacity of the formal banking sector in providing financial services to the vast majority (about 65\%) of the Nigerian population considered poor but economically active (CBN, 2010).

The effect of Bank of Industry lending on Micro Small and medium enterprises output does not present a bright future. Upon government policies on the stability of Nigerian economy through, micro, small and medium enterprises (MSMES) output despite the establishment of Bank of Industry (BOI) as one of the government policies to stabilize micro, small and medium enterprises (MSMES) by increasing the size of long term loans to (MSMES) and reduce rate of interest, a lot of problems seem to have persisted. Some of the problems include inability to access loan (Gloria and Cosol, 2011) high interest rate charges (Adnan, 2010) corruption and ineffective economic policies, Gbosi (2007) Mismanagement of fund which reduced rural-urban development (Odebiyi and Olaoye, 2012) and insufficient infrastructural facilities such as electricity, good road, network and good pipe borne water in Nigeria (Idowu, 2010).

The inability of Bank of Industry to impact positively on the micro, small and medium Enterprises output in Nigeria no doubt calls for investigation.

Perhaps the meekness of micro, small and medium enterprises output to be part of the key drivers of growth in Nigeria may be responsible for the lack of congruence between growth and the well being of Nigerians.

The question is to ascertain whether Bank of Industry lending are actually helping economic growth in Nigeria through micro, small, and medium enterprises; and whether such lending have any positive correlation with key microeconomic sectors such as micro, small and medium enterprises. There are the under pinning issues that this research will focus on.

The objective of research is determine the effect of Bank of Industry (BOI) loan size on micro, small and medium enterprises output in Nigeria; to ascertain the effect of Bank of Industry interest rate on micro, small and medium enterprises output in Nigerian; to determine the effect of availability of Bank of Industry credit proxies as total Bank of Industry BOI savings on micro, small and medium enterprises output in Nigeria.

The scope of this study is on the effect of developmental financial institution on micro small and medium enterprises in Nigerian focusing on Bank of Industry.

The period of the study is 12 years (2012-2013) and we want to know how the increase in BOI activities affects micro, small and medium enterprises in Nigeria. The study pays attention on Bank of Industry (BOI) loan size, Bank of Industry (BOI) interest rate, Bank of Industry total savings deposits loan repayment rate and its impact on the performance of economic growth through micro, small and medium enterprises in Nigeria.

\section{Literature Review}

\subsection{Conceptual Frame Work}

2.1.1. Concept of Development Financial Institution

Development Financial Institutions are created for the purposes of improving on the gaps of regular financial institution like commercial banks who have failed in providing credits to micro, small, medium enterprises. Therefore they are to act catalysts for accelerated economic growth and human resources development.

Development Financial Institutions are largely owned by the central Bank of Nigeria (CBN) and Ministry of Finance which acts on behalf of Federal Government and are to large extent mandated to provide financial services to sectors and projects that would contribute to the growth of the economy and promote real sector economy (Sanusi, 2012).

In Nigeria, they are many Development Financial Institutions with different objectives and mandates. They are Bank of Industry; Federal Mortgage Bank; Urban Development Bank of Nigeria, (etc).

The need to ensure that investible funds are provided for micro, small and medium Enterprises and other economic activities development as well as the lapses of deposit money Banks (DMBS) in serving the vast unserved rural markets informed the decision of Nigerian government to establish Bank of Industry in 2001.

Akingunola (2011) opines that there will be significant positive relationship between micro, small and medium enterprises and Economic growth in Nigeria if government intervene on the level of development financial institution interest rate on loan.

Adnan (2010) stated that Development Financial Institutions can help in the reduction of poverty of different categories of poor people by increasing the loan size and reducing the interest rate charged on loan which will help the growth of micro, small, and medium enterprises (MSMES) in Nigeria.

Ofoegbu et al. (2013) stated that micro small and medium enterprises will have significance positive impact on economic growth if developmental Financial Institutions in Nigeria reduce the size of their interest rate on loan and increase the size of the on long term bases.

The core mandate of Bank of Industry (BOI) is to provide financial assistance for the establishment of large, medium and small projects; as well as expansion, diversification and modernization of existing enterprises and reliability of oiling industries. The mission of the bank is to transform Nigeria's industrial sector and integrate it into the global economy by providing financial and business support services to existing and new industries to attain modern capabilities to provide goods that are competitive in both domestic and external markets (Sanusi, 2013).

The role of Bank of Industry in promoting micro, small and medium enterprises has been focused on the area of financing which covers the volume of loan to MSMES and the interest charged on that loan and advance. 
The development or the growth of micro, small and medium enterprises (MSMES) through effective financing options in Nigeria have generated a lot of debates among researchers, policy makers and entrepreneurs because of its immense cultivation to the economic growth of the country (Akingunola, 2011).

Again, Bank of Industry (BOI) volume of loan to MSMES have a working capacity facility of one year with provision for roll over or maximum of 15 years and the fund allows for moratorium in the loan repayment schedule (CBN, 2011 ). Bank of Industry (BOI) interest rate can be seen as the macro -policy indicator and defined as the cost faced by small, medium and large enterprises when borrowing from Bank of Industry, BOI 2013.

\subsubsection{Definition of Micro, Small and Medium Enterprises}

By the National policy on MSEMS point of view, enterprises may be classified by size sector, organization, technology and location.

These variables interact with one another in complex ways which must be taken into understanding the nature, characteristics, performance, problems and challenges of business enterprises. From the perspective of policy and planning, size provides the most practical basis for classification the usual criteria include one or more of the following; employment, turnover, assets and paid up capital.

Micro, Small and Medium scale enterprises in most developed economics and Nigeria is one of the main life were of the economy. Micro, Small scale Enterprises that are adequately managed and properly funded to help the government to achieve some macro-economic objectives which include employment creation, mobilization of local resources, mitigating rural, urban migration and poverty reduction. Micro, Small and Medium Scale Enterprises help in encouraging capacity utilization in agriculture, industries and income distribution and encourage development of local technology.

Agganwal (2001) defined micro, Small and Medium Enterprises as business enterprises having a maximum asset bane of N2O million including land and building. The number of employees is defined as "not less than 10 and not more than $300 "$.

The National council of Industries defined MSMES as those with fixed assets above 1 million excluding land but including working capital.

Essien (2001) stated that Micro, Small-Scale Industry is an industry with total capital, employed for over $\$ 1.5$ million but more than $\$ 50$ million, including per a labour size of 11-100 workers based on assessment of existing national perspectives on the taxonomy of MSMES, the National Policy on MSMES adopts a classification based on dual criteria: Employment and assets excluding land and building as follows.

Table-1. Definition of MSMES

\begin{tabular}{l|l|l|l}
\hline S/NO & SIZE CATEGORY & EMPLOMENT & ASSETS (NM) (excluding land and buildings) \\
\hline 1 & Micro Enterprises & Less than 10 & Less than 5 \\
\hline 2 & Small Enterprises & $10-49$ & 5 and less than 50 \\
\hline 3 & Medium Enterprises & $50-199$ & 50 and less than 500 \\
\hline \multicolumn{2}{l}{ Source: BOI $(2013)$}
\end{tabular}

Small forms are back bone of national development in Nigeria and for Nigeria to reach it's full potential in terms of economic and social development it cannot afford to ignore the importance of its indigenous micro, small and Medium enterprises and the contributions that they make to the country's economy. In this, world trade liberalization and the encouragement of foreign direct investment has to go hand in hand with a through and concentrate effort to help the growth and development of small business enhance development.

\subsubsection{The Relationship between (BOI) Variables and Micro, Small and Medium Enterprises MSEMES Output}

The relationship between Bank of Industry loan size and micro, small and medium enterprises output means the size of loan that Bank of Industry gives out to its customers especially the MSMES in Nigeria and the relationship between such loan to the growth of Nigerian economy through micro, small and medium enterprises output.

Lending which may be on short, medium or long term basis is one of the services that Bank of Industry does render to its customers. In other words, Bank of Industry BOI does grant loan and advances to individuals business organizations both large, medium and micro, small business enterprises as well as state governments in order to enable them embark on investment, industrial and developmental projects or activities as a means of cultivating towards the economy growth of the economy in general (Olokoyo, 2011).

How ever, Bank of Industry decision to lend out loans are influenced by a lot of factors such as the fear of the prevailing interest rate, the volume of deposits the level of bank liquidity ratio, size of approved fund available for lending and level of customers loan repayment (Kehinde and Adejuwon, 2011). The BOI loan size to MSMES has been on increase since the establishment of the bank since 2001. The increase of Bank of Industry loan size is expected to have some influence on micro, small and medium enterprises output which will in turn contribute to the growth of Nigerian economy but the level or degree of effort is unknown and it call for this study.

Bank of industry interest rate can be seen as the macro-policy indicator and defined as the cost faced by micro, small and medium enterprises when borrowing from Bank of Industry. The level of interest rate is expected to have effect on MSMES output. This is because low interest rate will help the MSMES to payback and as when due and contribute to economic growth.

Meanwhile, the relationship between Bank of Industry (BOI) interest rate and micro small and medium enterprises output using other manufacturing output micro small and medium enterprises in Nigeria, present indiscrimate

Result as shown in Figure I below. 


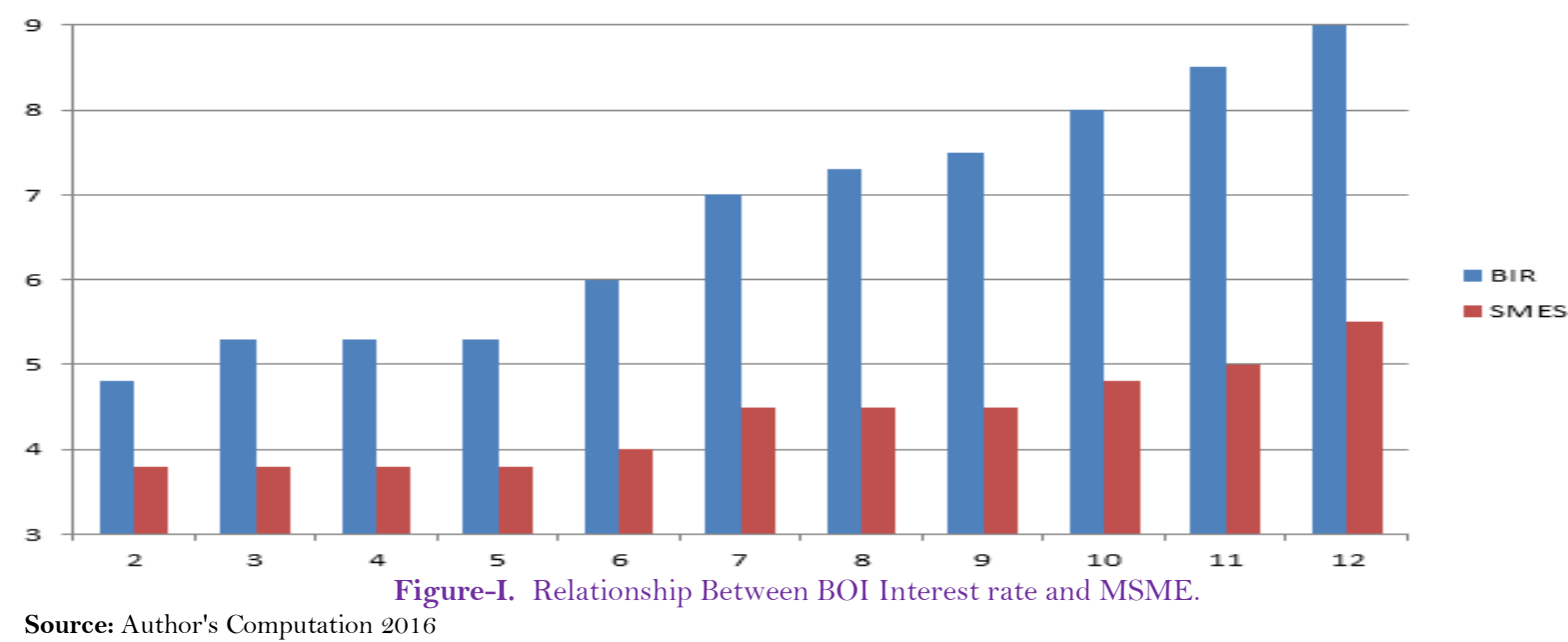

And contribute to economic growth.

Meanwhile, the relationship between Bank of Industry rate and Micro, Small and Medium Enterprises output using other manufacturing output. Micro, small and medium enterprises in Nigeria present indiscriminate result as shown in Figure 1 below:

\subsection{Empirical Revierw of Related Literature}

Previous attempts have been made to empirically examine the implications of developmental financial institutions on micro, small medium enterprises includes but not limited to the following. Idowu (2010) investigated the impact of micro credit banks on micro, small and medium-sized enterprises in Nigeria using simple random sample techniques and descriptive statistics which involves simple percentage graphical charts and illustrations. The findings reveal that significant number of the MSMES benefited from the development financial institutions loans even though only few of them were capable enough to access the micro credit institutions loans towards promoting their market share, product innovation achieving market excellence and the overall economic company competitive advantage.

The study suggested that provision of government sufficient infrastructural to support micro, small, and medium enterprises in Nigeria.

Emmanuel and Daniya (2012) examine the development of micro, small and medium scale enterprises; the role of government and other financial institutions employing the variable of micro, small and medium enterprises using spearman Rho correlation and descriptive statistics. It was discovered that financial institutions provide the necessary financial-lubricant that enhance the development of micro small and medium enterprises in Nigeria employing panel data, and multiple regression analysis, Abiola (2012) studied the effects of micro finance on micro and small enterprises growth in Nigeria using survey of 502 randomly selected enterprises financed by micro finance banks in Nigeria. The result indicates a strong evidence that access to micro finance does not enhance growth of micro and small enterprises in Nigeria and that other firm level characteristics such as business size and business location have positive effect on enterprises growth in Nigeria. The study also suggests that there should be a recapitalization on developmental financial institutions to enhance growth and expansion in Nigeria. Agu et al. (2013) investigated the impact of micro, small and medium enterprises on economic growth in Nigeria using ordinary least square and co-integration test.

They found that there is a robust long run relationship between micro, small and medium enterprises and economic growth in Nigeria.

Using statistical package for social sciences (SPSS) which generated the frequency distributions, means standard deviations, variances, analysis of variance, standard errors, chi-square statistics, correlations and t-test covering the period of 1990-2004, Onugu (2005) examined the problems and prospects of micro small and medium enterprises in Nigeria. The study found SMES have played and continue to play significant roles in the growth development and industrialization of many economics in the world. The study supports the conclusion that the problems of SMES in Nigeria as mentioned in the introductorychapter are mismanagement, access to finance, infrastructure, government policy inconsistence and bureaucracy, environmental factors among others.

\subsection{Theoretical Framework}

\subsubsection{Financial Growth Theory}

Financial Growth Theory was developed by Berger and Udell (1998) and was used by Bahajide (2011) and Akande (2012). This theory was anchored on the small business as where the financial needs and financing options change as the business grows and it becomes more experience and less informative. They further suggested that forms rely on a size/age must rely on initial insider finance, trade credit and/ or developmental financial institutions.

This theory predicts that as firms grows; it will gain more access to venture capital as a source of intermediate equity and mid-term loans as a source of intermediate debt. At the final state of the growth theory, as the form becomes older, more experienced and more informative transparent, it will likely gain access to long term debt.

This study anchored on financial growth theory because the theory predicts that as firm grows, it will gain more access to investment capital as a source of intermediate equity. The implications of this theory is that micro, small and medium enterprises need internal source of finance before looking for the external fund from the development financial institutions especially Bank of Industry.

This is because the size of the loan and lack of information on the quality of operation of the micro, small and medium enterprises force lenders to protect their investment by demanding higher rates of return, which come in the form of high interest rate, and high cost of capital for the small firm. 
In an attempt to avoid higher cost of capital, smaller firms are then forced to use more short-term loan, which carries lower costs but raises the firms risk and reduce profitability and growth.

\section{Methodology}

\subsection{Research Design}

The study employs the export facto design. This is the type of research involving events that have already taken place (Onwumere, 2009). The data already exist as no attempt would be made to control or manipulate relevant independent variables. It aims at determining and measuring the relationship between one variable and another or the effect of one variable on another variable. The multiple linear regression analysis based on the classical regression methodology was used to form the main procedure to be followed in this work. The ordinary least square (OLS) techniques is chosen not only because of its computational simplicity but because it possesses some desirable statistical properties such as linearity, unbiasedness minimum variance zero mean value of the random term etc (Koutsoyiannis, 2003; Gujarati, 2005).

\subsection{Method of Data Analysis}

The study is largely a quantitative techniques and it builds on existing studies and methodologies as depicted in chapter two. The analytical procedures adopted in this study to test the hypotheses are discussed below and these include.

A multiple regression model using ordinary least square (OLS) regression analysis, unit root test (etc) all thesis models are used in order to avoid a number of challenges in econometric model.

The choice of using these tools was that the empirical works reviewed in this study all was based on mathematical analysis and was not based on hearsay argument.

\subsection{Model Specification}

This study is be largely quantitative and builds on existing studies and methodologies specially, this study adopts the popular growth equation and followed with a multiple regression model, thus the growth equation is stated as:

$\mathrm{Q}=\mathrm{f}(\mathrm{K}, \mathrm{L})---(1)$

Where;

$\mathrm{Q}=$ output of the economy

$\mathrm{K}=$ Capital

$\mathrm{L}=$ Labour

In this study, the researcher follow Idowu (2010); Emmanuel and Daniya (2012); Abiola (2012); Agu et al. (2013); Gbandi and Amissah (2014) but in a modified version. This model therefore estimates that;

$\mathrm{Yt}=\mathrm{B}_{\mathrm{o}}+\mathrm{Xt}+\mathrm{Ut}$ (2)

However, the linear function of the above notation is hereby modified and estimated as follows:

$\mathrm{Yt}=\mathrm{B}_{\mathrm{O}}+\mathrm{B}_{1} \mathrm{xt}-$

$\mathrm{Yt}=$ Dependent variable (MSMES, OMSMES)

$\mathrm{X}=$ Independent variables

$\mathrm{Xt}_{1}=$ BOI Interest Rate (Interate)

$\mathrm{Xt}_{2}=$ BOI Loan size (LS)

$\mathrm{Xt}_{3}=$ BOI Total Savings Deposit (TSD)

$\mathrm{Xt}_{4}=$ BOI Repayment Rate $(\mathrm{RR})$

$\mathrm{B}_{\mathrm{O}}=$ Intercept on $\mathrm{Y}$ axis

$\mathrm{B}_{\mathrm{I}}-----\mathrm{B} 6=$ Are the regression coefficients to be estimated.

$\mathrm{Mt}=$ Error or disturbance term

$\mathrm{EXRt}=$ Exchange rate

INFLt $=$ Inflation rate

The equation above is being reinstated to carry its parameters as follows;

OMSMESt $=\mathrm{B}_{\mathrm{o}}+\mathrm{B}_{1}$ INTRATEt $+\mathrm{B}_{2} \mathrm{LSt}+\mathrm{B}_{3}$ TSDt $+\mathrm{B}_{4} \mathrm{RRt}+\mathrm{B}_{5}$ EXRt $+\mathrm{B}_{6} \mathrm{INFLt}+\mathrm{Nt}$

\section{Findings}

Table-2. Results of Anderson Darling Normality Test on the Chosen variables.

\begin{tabular}{l|l|l|l}
\hline Variables & Skewness & AD (Probability) & Normal Distributor \\
\hline OMSMES & 0.653410 & $3203967(0.023415)$ & YES \\
\hline BIR & 0.3451123 & $3.056347(0.234156)$ & YES \\
\hline BLB & 0.564901 & $3.052314(0.217634)$ & YES \\
\hline BTSD & 0.294560 & $2.033647(0.217234)$ & YES \\
\hline INR & 1.172640 & $1.973619(0.342561)$ & YES \\
\hline EXR & 0.435167 & $2.190456(0.453240)$ & YES \\
\hline \multicolumn{2}{l}{ Source: Authors' calculation 2016 (Extracted from E-view $7.00 u t p u t)$} & YES \\
\hline
\end{tabular}

Source: Authors' calculation 2016 (Extracted from E-view 7.0 output).

Anderson Darling normality test uses means, standard deviation, skewness and probability in line with minimum and maximum values of the sense to construct the distribution which can be compared with the equivalent value. The result above was performed on the variables to examine the extent to which they could affect the results of the study. 
The results shows that all the variable are normally distributed.

Table-3. Error Correction Model (ECM) Result

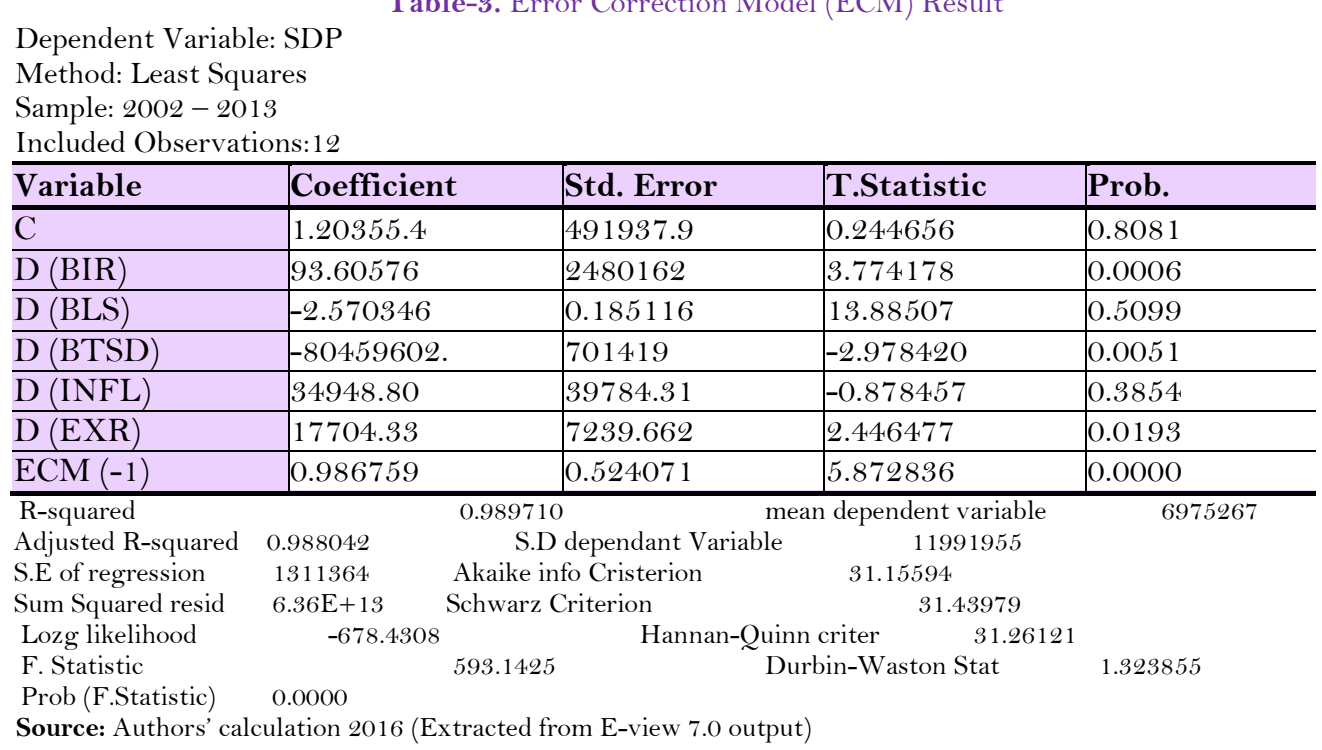

The figures from the error correction are quite revealing. The significance of ECM holds that a positive and statistically significant error correction model coefficient is a necessary condition for the variables to be cointegrated.

The error corrected coefficient is 0.986759. the positive sign of the co-efficient satisfies one condition while the fact that 0.986759 is different from zero satisfies the second condition of statistical significance. The coefficient revealed that the speed of adjustment between the short-run and long-run realities of the co-integratory equations is 98.68 every year. Again, the computer $\mathrm{R}^{2}$ value of 0.98710 which is the coefficient of multiple determinations indicates that our model satisfies the goodness of fitness.

The value shows that $98.97 \%$ of the variations in the output of micro, small and medium enterprises (OMSMES) are adequately explained by changes in BOI Interest Rate (BIR), BOI Loan size (BLS) BOI Total Deposit (BTSD), BOI Repayment Rate (BRR), Inflation Rate (INFL), and Exchange Rate (EXR).

Further, the joint influence of the explanatory variables on the dependent variable is statistically significant. This is confirmed by F-test probability which is statistically zero, equally, the Durbin Waston is 1.32 approximately. Using 5\% level of significant 6 explanatory variables and 12 observations the tabulated Durbin Waton statistics for lowers and upper limit are 1.261 and 1.722 respectively.

Finally, the results from the above table 4.2 shows that BOI Interest Rate (BIR), Inflation Rate (INEL) and Exchange Rate (EXR) has significant and positive effect on the development of micro, small and medium Enterprises in Nigeria Proxy for output of micro, small and medium enterprises (OMSMES), while BOI Loan size (BLS), BOI Total Savings Deposit (BTSD) and BOI Repayment Rate (BRR) has negative implication on the development of micro small and medium Enterprises in Nigeria Proxy for output of micro, small and medium enterprises (OMSMES).

\section{Conclusion}

The study focuses on the implications of Bank Industry BOI operation the Micro, Small and Medium Enterprises output in Nigeria.

The study used ordinary least square model on a time series data from 2002-2013. The regression result reveals that the difference in beta coefficient of the variables representing the bank of industry operation shows the different contributions of the variables to the micro, small and medium enterprises.

In conclusion, Bank of Industry interest rate has been relatively high over the years and has significant positive effect on micro, small and medium enterprises output in Nigeria, while BOI loan size has no significant positive effect on the development of micro, small and medium enterprises output in Nigeria.

This suggests that low interest rate on loan will help the development of micro, small and medium enterprises output and as well reduce the level of poverty in Nigeria.

Also high level of loan and advances from BOI to MSMES will enhance the growth of micro, small and medium enterprises.

\section{Recommendations}

Based on the findings of the study the following recommendations are proffered towards enhancing implications of Bank of Industry operations on the development of micro, small and medium enterprises output in Nigeria.

1. Bank of Industry should provide loans and advances to the micro, small and medium enterprises in Nigeria. This is because of its positive effect on interest rate on the development of MSMES output in Nigeria.

2. There is need to redirect Bank of Industry focus towards making Nigeria a producer nation through micro, small and medium enterprises output which in turn would lead to economic growth and development.

3. Interest rate should be reduced by the financial institutions especially development financial institutions to enhance the micro, small and medium enterprises output in order to generate a corresponding increase in economic growth. 


\section{References}

Abiola, B., 2012. Effect of micro finance on micro, and small enterprises (MSES) growth in Nigeria. Asian Economic and Finance Review, 2(4): $2-14$.

Adnan, A., 2010. Role and performance of micro credit in Pakistan. Department of Economics, University West, 3(2): $26-35$.

Agganwal, B., 2001. Participatory exclusions, community forestry and gender: An Analysis for South Asia and a conceptual framework. World Development, 29(10): 1623-1648.

Agu, A., K.P. Ojimadu and C. Ogu, 2013. The impact of small and medium scale enterprises on economic growth in Nigeria. Retrieved from www.ircab.foundation.ora [Accessed 22nd July, 2014].

Akande, O.O., 2012. Performance analysis of micro finance banks on woman enterprises in Oyo State Nigeria. Journal of Organizational Psychology and Educational Studios, 1(3): 168-173.

Akingunola, R.O., 2011. Small and medium scale enterprises and economic growth in Nigeria: An assessment of financing options. Pakistan Journal of Business and Economic Review, 2(1): 78-97.

Bahajide, A., 2011. Effects of micro finance on micro, and small enterprises (SME) growth in Nigeria. Asian Economics and Financial Review, 2(4): 1-14.

Bank of Industries (BOI), 2012. Development of SMEs in Nigeria. Publication of Bank of Industry.

Berger, A. and G. Udell, 1998. The economics equity and debt. Journal of Banking and Finance, 3(6): $34-42$.

BOI, 2013. Annual and Economic Report.

CBN, 2010. CBN Economic and Financial Report, 52(3): 52-60.

CBN, 2011 Economic Report.

Central Bank of Nigeria (CBN), 2012. N200 billion intervention fund for Re-financing and restructuring of bank's loan to the manufacturing sectors. CBN Annual Publication.

Douglas, B.E., 2012. Impact of micro finance bank on economic growth and development of Nigeria. Unpublished. Research Project Submitted to the Imo State Polytechnic. pp: 3-50.

Emmanuel, O.O. and A.A. Daniya, 2012. Development of small and medium enterprises: The role of government and other financial institutions. Arabian Journal of Business and Management Review, 1(7): 16-29.

Essien, O.E., 2001. The role of development finance institutions (DFIs) in the financing of small-scale industries (SSIs). Lagos: Central Bank of Nigeria, 25(3).

Gbandi, E.C. and G. Amissah, 2014. Financing options for small and medium enterprises (SMEs) in Nigeria. European Scientific Journal, $10(1): 327-340$.

Gbosi, A.N., 2007. Human resources development and manpower planning in Nigeria. Yenogua Nigeria: A Publication of Godsisi Press Ltd.

Gloria, E.D. and T.M. Cosol, 2011. Microcredit and women empowerment: An empirical case-study based in Cataloria. Published Research Project Submitted to the Department of Economics, University of Barcelona. pp: 2-15.

Gujarati, D.N., 2005. Basic econometrics. 5th Edn., New York: McGraw Hill.

Idowu, K.O., 2010. A preliminary investigation into the cousal relationship between micro finance banks and economic growth in Nigeria. CBN Economic and Financial Review, 43(3): 29-50.

Kehinde, J.S. and K.D. Adejuwon, 2011. Financial institutions as a catalyst to economic development: The Nigerian experience. European Journal of Humanities and Social Sciences, 8(1): 323-334

Koutsoyiannis, D., 2003. Modern econometrics. Publications in Scientific Journals, 26(13): 267-300.

Odebiyi, O.C. and O.J. Olaoye, 2012. Small and medium scale agriculture enterprises (SMES) development in Ogun State, Nigeria: The role of micro finance banks. Libyan Agriculture Research Centre Journal International, 3(1): 01-06.

Ofoegbu, E.O., P.A. Akianbi and A.I. Joseph, 2013. Effects of contextual factors on the performance of small and medium scale enterprises in Nigeria: Case study of Ilorin metropolis. Advances in Management and Applied Economics, 3(1): 95-114.

Olokoyo, F.O., 2011. Determinants of commercial banks lending behaviour in Nigeria. International Journal of Financial Research, 2(2): 112.

Onugu, B.A.N., 2005. Small and medium enterprises in Nigeria: Problemsand prospects. Retrieved from www.gogle.come.Extracted [Accessed 5/6/2013].

Onwumere, J.U.J., 2009. Business and economic research methods. Lagos: Don - Vinton Ltd.

Sanusi, L.S., 2012. The role of development financial institutions in infrastructural development: What Nigerian can learn from BNDES and the India infrastructural finance. Key Note Address Presented at the 3dr ICRCPPP Stake Holders Forum. pp: 6-7.

Sanusi, L.S., 2013. Transforming Nigerian economy through the establishment of development financial institution. A Paper Presental at the International Economic Summit at United State of America.

\section{Bibliography}

Nwankwo, O., G.A. Olukotu and A. Emmanuel, 2013. Impact of microfinance on rural transformation in Nigeria. International Journal of Business and Management, 8(19): 99 . 
Appendix-1. Disbursement of loan to Micro, Small and Medium Scale Industry by the Bank of Industry for the

\begin{tabular}{l|l|l|l|l}
\multicolumn{2}{l|}{ period of Twelve $(12)$ years. } & RATE & AMOUNT & N \\
\hline S/NO. & YEARS & INDUSTRIES & 8 & $55,360,000.000$ \\
\hline 1 & 2002 & Oil and Gas & 8 & $55,360,000.000$ \\
\hline 2 & 2003 & Agro -allied & 10 & $69,200,000.000$ \\
\hline 4 & 2004 & Cold Roll Mill & 10 & $69,200.000 .000$ \\
\hline 5 & 2005 & Solid Minerals & 8 & $55,360.000 .000$ \\
\hline 6 & 2006 & Agricultural Sector & 8 & $55,360.000 .000$ \\
\hline 8 & 2007 & Petrol Chemical & 8 & $55,360.000 .000$ \\
\hline 9 & 2008 & Coal and Mine & 8 & $55,360.000 .000$ \\
\hline 10 & 2009 & Communication Sector & 8 & $55,360.000 .000$ \\
\hline 11 & 2010 & Information Technology & 8 & $55,360.000 .000$ \\
\hline 12 & 2011 & Iron Ore & 8 & $55,360.000 .000$ \\
\hline Source: & 2012 & Glasxosmith Beechem Plc & 8 & $55,360.000 .000$ \\
\hline
\end{tabular}

Source: BOI (2012)

Citation | Nwankwo, Odi; James, S.O. (2017). Empirical Study of Bank of Industry's Loan to the Development of Micro, Small and Medium Enterprises in Nigeria: (2002-2013). Journal of Banking and Financial Dynamics, 1: 1-8.

History:

Received: 23 August 2016

Revised: 30 September 2016

Accepted: 10 October 2016

Accepted: 10 October 2016

Licensed: This work is licensed under a Creative Commons

Attribution 3.0 License $(\mathrm{cc})$

Publisher: Eastern Centre of Science and Education

Eastern Centre of Science and Education is not responsible or answerable for any loss, damage or liability, etc. caused in relation to/arising out of the use of the content. Any queries should be directed to the corresponding author of the article.
Contribution/Acknowledgement: All authors contributed to the conception and design of the study.

Funding: This study received no specific financial support.

Competing Interests: The authors declare that they have no conflict of interests.

Transparency: The authors confirm that the manuscript is an honest, accurate, and transparent account of the study was reported; that no vital features of the study have been onitted; and that any discepancies from the study as planned have been explained.

Ethical: This study follows all ethical practices during writing. 